\title{
多追従モデルを用いた道路合流部における渋滞の緩和*
}

\author{
井口智 彦*1, 脇田 佑希子*1, 清 水 光 輝*1 \\ 玉 城龍洋*2, 北栄 輔*3
}

\section{Improvement of Traffic Jam at Merging Point of Roads by Using Multi-Car-Following Model}

\author{
Tomohiko IGUCHI, Yukiko WAKITA, Hikaru SHIMIZU, \\ Tatsuhiro TAMAKI and Eisuke KITA*4 \\ ${ }^{* 4}$ Graduate School of Information Science, Nagoya University, \\ 1 Furo-cho, Chikusa-ku, Nagoya"shi, Aichi, 464-8601 Japan
}

\begin{abstract}
The improvement of traffic jam at a merging point of roads by using multi-car-following model is described in this paper. In this study, the stability of the model is analyzed for determining model parameters for improving traffic jam. Cellular automata (CA) simulation based on the model is applied for simulating the traffic flow near merging point of roads. The results are compared with them by the simple car-following model. The result shows that the use of multi-car-following model improves traffic jam near the merging point of roads.
\end{abstract}

Key Words : Car-Following Model, Bexelius Model, Cellular Automata (CA), Merging Road Point

\section{1. 緒論}

日本の自動車保有台数は年々増加しており，交通渋 滞は悪化の一途を辿っている. 交通啮滞は一般的に工 事・事故などによる渋滞と自然渋滞に区分される．自 然泚滞とは，道路あたりの自動車台数が増加して起こ る啮滞や，トンネルやサグ等の道路形状によって起こ る泚滞のことである。自然渋滞の一つに，道路合流部 で観測される㗪滞がある，合流部では，合流車線から 車両が合流する事によって渋滞が引き起こされる。こ の問題を解決するための研究はいくつか行われている. 西らは，合流区間の一部に区画線を引いて，本線走行 車両と合流レーン走行車両を交互に配置させることで ジッパー合流を実現し，渋滞緩和できると述べている (1).しかし，合流時に車間距離が急激に狭くなって， 合流部直前の車両は速度を落とすため，車間距離が十 分広くなければ，ジッパー合流でも渋滞を防ぐことは 容易でないと想像される.

本研究では，本線車両を運転する運転者为自車両の 速度加減速を適切に行うことで，合流車両によって生 じる䠖滞を緩和することを考える．車両合流時に合流 車両からもつとも強く影響を受けるのは，合流車両の

\footnotetext{
* 原稿受付 2009 年 3 月 23 日。

*1 名古屋大学大学院情報科学研究科(画) 464-8601 名古屋市干 種区不老町 1).

*2 字部工業高等専門学校経営情報学科(亚 755-8555 宇部市常 盤台 2-14-1)

*3 正員, 名古屋大学大学院情報科学研究科.

E-mail:kita@is.nagoya-u.ac.jp
}

直後を走る本線車両である。合流された車両より後方 の本線車両には，前の車両の減速挙動が時間差を招い て順次伝わっていく。この反応遅れが橴滞の一因と考 えられる. 本研究では前方車両 1 台だけでなく, 複数 の前方車両に忘じて速度を制御することを考える。な お，前方車両 1 台だけに応じて速度制御するモデルを 追従モデル，複数の前方車两に忘じて速度制御するモ デルを多追従モデルとする。

車両の運転において，複数の前方車両を考慮するこ との有効性は経験的にも指摘されているが, 直前車両 が大型車雨の場合，それより前の車雨挙動を正確に把 握すること注難しい。しかし，近年発達している高度 道路交通システム (ITS) の技術を用いれば，複数の前 方車両の位置を把握することは可能である．本研究で 述心゙る追従モデルの場合が前者に，多追従モデルの場 合が後者に相当する.

交通流の研究の中で，追従モデルはもっとも長い歴 史を持つ交通流模型の一つである地(3)，追従モデルで は，前方車両に応答して自車両の速度を決定する。そ の一つに，前方車両との相対速度に応じて加減速する Bexelius モデル(4)がある. 本研究では, Bexelius モデ ルを改良して，3台の前方車両に応じて速度制御する モデル娄应張 Bexelius モデルとして示す.このモデル を適用することでスムーズな速度遷移を行うことがで き，合流部における渋滞緩和が実現できることを示す。 合流車両の影響は，連続して合流してくる車両の台 
数と合流パターンによって異なる、そこで，解析例で は，1台の車両が合流する場合，2台の車雨が連続して 合流する場合，3台の車雨が連続して合流寸る場合に 加え，ジッパー合流する場合の4つのパターンを扱う。 ジッパー合流の最小パターンは2 台が本線車両の間に 合流する場合なので，これをシミュレーションするた めに 3 台の前方車雨考慮する多追従モデルを扱う.

本論文の構成は以下の通りである，2章では，追従 モデルと桩張 Bexelius モデルを示し，これらモデルの 安定性解析からパラメー夕を設計する．３章では，七 ルオートマトン (CA) によるシミュレーションについ て説明する，4章では，4種類の車雨合流パターンを 考え, それぞれの交通流の挙動を解析打る. 最後に, 5 章で本研究の結論を述べる。

\section{2. 車両追従モデル}

2.1 Bexelius モデル 追従モデルの基本的な考 え方は，「加速度は，先行車からの刺激と，乙れに対す る運転者の反応感度によって決まる.」といえる。こ の考えに基づき，遅れ時間を考慮したモデルの一つが 次式である(5).

$$
\ddot{x}_{n}(t+\tau)=k \cdot\left\{\dot{x}_{n-1}(t)-\dot{x}_{n}(t)\right\}
$$

ここで，時間 $t$ での車両 $n$ の位置を $x_{n}(t)$ と示す。従つ $\tau, \ddot{x}_{n}(t)$ は車両 $n$ の加速度老表守。 $\tau$ は遅れ時間， $k$ は前方車両との感受率である。

このモデルの他にも，さまざまなモデルが提案され ている(2).このうち, Bexelius は, 以下のモデルを提 案している(4).

$$
\begin{aligned}
\ddot{x}_{n}(t+\tau) & =k_{1} \cdot\left\{\dot{x}_{n-1}(t)-\dot{x}_{n}(t)\right\} \\
& +k_{2} \cdot\left\{\dot{x}_{n-2}(t)-\dot{x}_{n}(t)\right\}
\end{aligned}
$$

この場合， 2 台の前方車両との相対速度 $\dot{x}_{n-i}(t)-$ $\dot{x}_{n}(t)(i=1,2)$ に忘じて加速度が変化するようにモデ ル化されている， $i$ 壮前方車両との番号差を表し， $k_{i}$ は各前方車両との感受率である。

2.2 拡張 Bexelius モデル 本研究では， 3 台の 前方車両との相対速度に忘じて加速度が変化するモデ ルを考え，㹡張 Bexelius モデルとよぶことにする。

多数の車両が連なって走行するとき，先頭車両の前 に車両が合流すると，その影響は徐々に後方車両に伀 わる，影響が早く収束するほど交通啮滞の影響は少な く，安定性が高いといえる，以下では，これを実現す る拡張 Bexelius モデルのパラメータを設計する。
2.2.1 安定性解析 搪張 Bexelius モデルは次式 で表される。

$$
\begin{aligned}
\ddot{x}_{n}(t+\tau) & =k_{1} \cdot\left\{\dot{x}_{n-1}(t)-\dot{x}_{n}(t)\right\} \\
& +k_{2} \cdot\left\{\dot{x}_{n-2}(t)-\dot{x}_{n}(t)\right\} \\
& +k_{3} \cdot\left\{\dot{x}_{n-3}(t)-\dot{x}_{n}(t)\right\}
\end{aligned}
$$

式 (3)において平衡状態 $x=x_{0}$ を考え，之の辺りの微

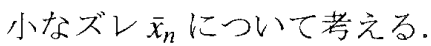

$$
x_{n}=x_{0}+\bar{x}_{n}
$$

式(4) 老式 (3)八代入すると,

$$
\begin{aligned}
\overline{\dot{x}}_{n}(t+\tau) & =k_{1} \cdot\left\{\overline{\dot{x}}_{n-1}(t)-\overline{\dot{x}}_{n}(t)\right\} \\
& +k_{2} \cdot\left\{\overline{\dot{x}}_{n-2}(t)-\overline{\dot{x}}_{n}(t)\right\} \\
& +k_{3} \cdot\left\{\overline{\dot{x}}_{n-3}(t)-\overline{\dot{x}}_{n}(t)\right\}
\end{aligned}
$$

となる. 式 (5) の解として次式が考えられる.

$$
\overline{\dot{x}}_{n}(t)=A_{n} \cdot e^{j \cdot w \cdot t}
$$

ここで，jは虚数単位， $w$ は振動数である.

モデルの安定条件のためには，全てのwにおいて， $n \rightarrow \infty$ の時, $A_{n} \rightarrow 0$ になる必要がある. 式 (6) を式 (5) 一代入寸ると次式老得る。

$$
A_{n}=\frac{k_{1} \cdot A_{n-1}+k_{2} \cdot A_{n-2}+k_{3} \cdot A_{n-3}}{k_{1}+k_{2}+k_{3}+j \cdot w \cdot e^{j \cdot w \cdot \tau}}
$$

式 (7) 㰞次式のように書き直すことができる。

$$
A_{n}=\frac{C_{1}}{z_{1}^{n}}+\frac{C_{2}}{z_{2}^{n}}+\frac{C_{3}}{z_{3}^{n}}
$$

ここで， $C_{1} ， C_{2}, C_{3}$ は式(7) を整理して生じる定数係 数である。また， $z_{1}, z_{2}, z_{3}$ 怔特性方程式

$$
1=\frac{k_{1} \cdot z+k_{2} \cdot z^{2}+k_{3} \cdot z^{3}}{k_{1}+k_{2}+k_{3}+j \cdot w \cdot e^{j \cdot w \cdot \tau}}
$$

の解である。

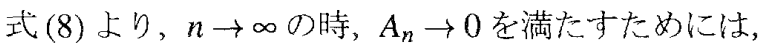
全ての $w$ において, $\left|z_{i}\right|>1(i=1,2,3)$ でなければな らない。

そこで, 式 (9) の解 $z_{i}$ が， $\left|z_{i}\right|>1$ を満たすように パラメー夕 $k_{1}, k_{2}, k_{3}, \tau$ 定める.

計算の簡略化のため，一次までのテイラー展開によ り次式のように近似する。

$$
e^{j \cdot w \cdot \tau} \approx 1+j \cdot w \cdot \tau
$$




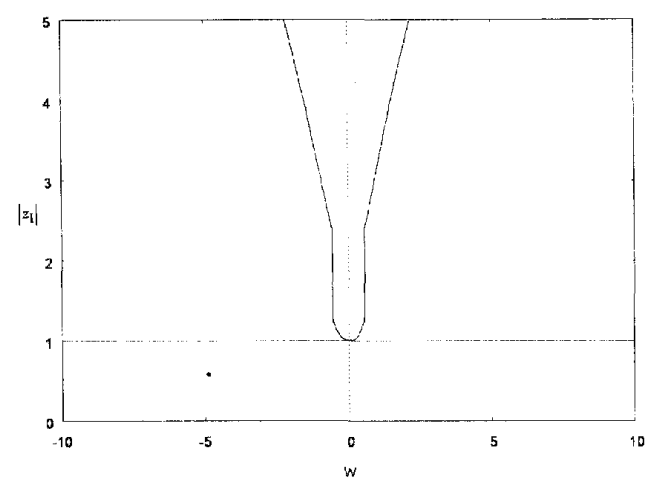

Fig. 1 Graph of Function $\left|z_{1}\right|$

2.2.2 パラメータ設計 式(3)において, $k_{1}, k_{2}$ ， $k_{3}$ は各前方車両に対する感受率を表す，感受率とは， 先行車に対する反応の強さを表す正の定数である。従っ て，1台前方車両一の感受率 $k_{1}$ は 2 台前方車両一の感 受率 $k_{2}$ よりも大きいと考えられる。 そこで， $k_{1} ， k_{2}$, $k_{3}$ に関して，以下の条件を扔く。

$$
k_{1} \geq k_{2} \geq k_{3}
$$

上式を満たすように $k_{1}, k_{2}, k_{3}, \tau$ を以下の值におく.

$$
k_{1}=0.15, k_{2}=0.10, k_{3}=0.06, \tau=1.0
$$

これらのパラメータを式(9)に代入し， $z_{1}, z_{2}, z_{3} を w の$ 関数とする。これらのうちで絶対值が最小上なる $\left|z_{1}\right|$ のグラフを図 1 に示す。綐軸は $\left|z_{1}\right|$, 横軸は $w$ であ る.これよりパラメータが式(12)の值をとるとき，全 てのwで $\left|z_{1}\right|>1$ を満たしていることが分かる。ここ では示していないが， $\left|z_{2}\right|$ と $\left|z_{3}\right|$ も同様である.従っ $\tau, k_{1}, k_{2}, k_{3}, \tau$ が上記の值を取る時，拡張 Bexelius モデルは安定であるといえる。

$2 \cdot 3$ 追従モデルのパラメータ＼cjkstart拡張 Bexelius モ デルとの比較のために，式(1)の追従モデルを用いる. 式 (1)の安定性解析を 2.2 節と同㥞に行うと, 次の条 件式を得る。

$$
k<\frac{1}{2 \tau}
$$

ここで，遅れ時間 $\tau$ を拡張 Bexelius モデルと同じ $\tau=1.0$ (秒) とすると， $k$ の条件式は次式となる.

$$
k<0.5
$$

このモデルの $k$ は拡張 Bexelius モデルにおける $k_{1}, k_{2}$, $k_{3}$ の和と等しく置くことにする。 つまり，

$$
k:=k_{1}+k_{2}+k_{3}=0.31
$$

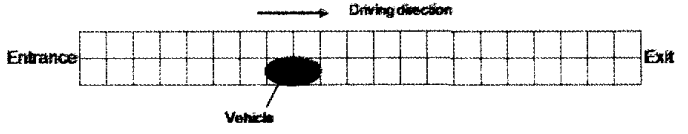

Fig. 2 Cell-Representation of Road

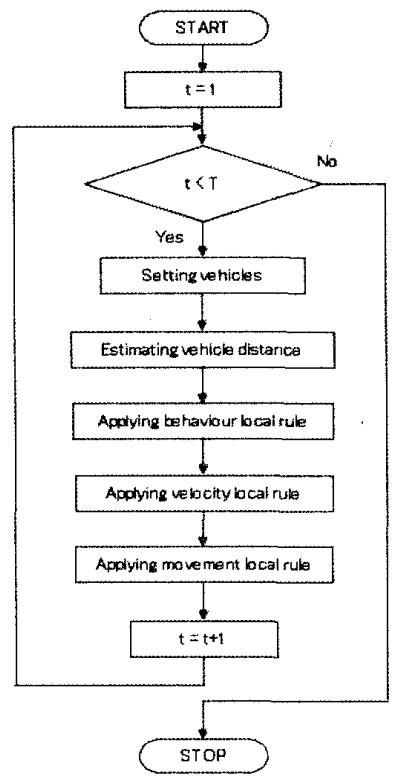

Fig. 3 Simulation Process

\section{CA によるモデル化}

3.1 道路のモデル化とシミュレーションの流れ 本研究では自動車専用道路を考え, セルオートマト ンでシミュレーションする.

3.1.1 解析領域 解析領域任正方形セルの集合 として表現する．1 セルのサイズは縦 3(m)，横 3(m) である. 1 台の車両は 2 セルで表現するので，サイズ は縌 3(m)，横 6(m) となる．道路と車両の例を図 2 に 示寸，車両は解析領域の左端から設定された確率で流 入守る。

3.1.2 シミュレーションの流れ 図 3 にシミュ レーションの流礼を示す。最初にタイムステップ 1 が代入され，初期化される。ここで，1タイムステッ プは実時間では 0.1 秒である。このタイムステップ がシミュレーション実行時間 $T$ になるまで，車両の配 置, 車間距離の測定, 行動ローカルルールの適用, 速 度ローカルルールの適用, 移動ローカルルールの適用 を繰り返す。な㧍，解析例では $T=200$ タイムステッ プとしている.

\section{$3 \cdot 2$ ローカルルール}

3.2.1 車間距離と安全車間距離車両が左車線 を走行する場合を図 4(a)に，車両が右車線を走行する 場合を図 4(b) に示寸，黒い本両が自車両を，灰色の車 


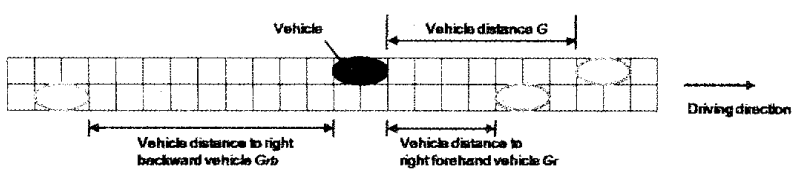

(a) Vehicle driving on left line

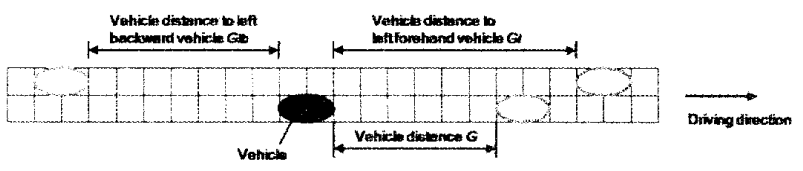

(b) Vehicle driving on right line

Fig. 4 Definition of Vehicle Distance

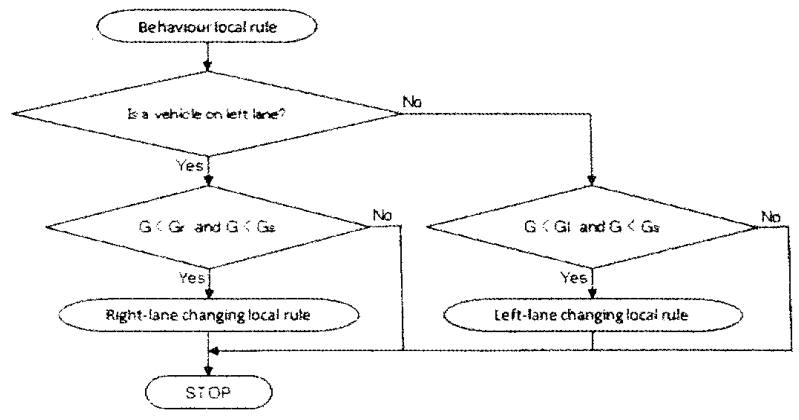

Fig. 5 Behavior Local Rule

雨が他車両を示す。

車両が左車線を走行しているとき(図 4(a)), 前方車 両との車間距離 $G$, 右車線 $G_{r}$, 右車線の後方車両との車間距離 $G_{r b}$ を計测する. 車両が右車線を走行しているとき(図4(b)) も同様であ $り$, 前方本雨との車間距離 $G$, 左車線の前方車耐との 車閒距離 $G_{l}$, 左車線の後方車両との車間距離 $G_{l b}$ を計 測する。これらの值は，後述するローカルルールにお いて車両行動の決定に用いる.

本研究では，車両は前走車に対して一定の安全な車 間距離老保ちながら走行すると考光る。この車間距離 定安全車間距離 $G_{s}$ と名付ける：各車両は前走車上の 車間距離が $G_{s}$ より大きければ加速し，小さければ減 速する。本研究では，実測データから測定された次式 の安全車間距離 $G_{S}$ 老採用与る(6).

$$
G_{s}=0.0029 \cdot v^{2}+0.3049 \cdot v
$$

ここで，vは車雨速度を示す。

$3 \cdot 2 \cdot 2$ 行動ローカルルール 行動ローカルルー ルでは，車両がどの近傍セルに移動するかを決定する。 そのフローチャートを図 5 に示す.

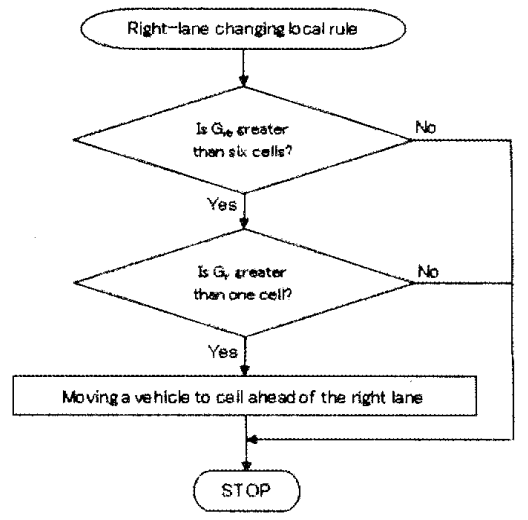

Fig. 6 Right-Lane Change Local Rule

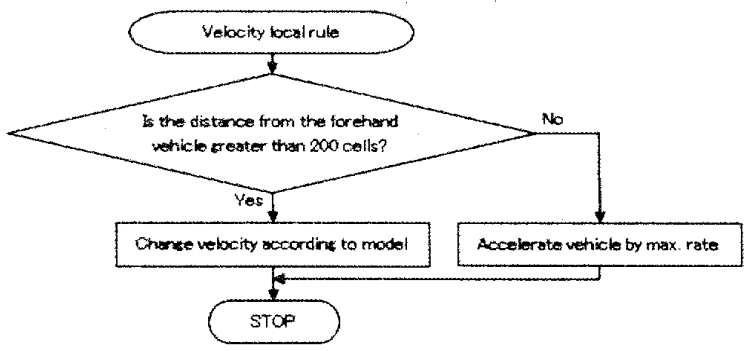

Fig. 7 Velocity Local Rule

最初に自車両の存在車線を確認する。自車両が左車 線に存在する場合は，直進加右車線への車線変更の2 種類の行動パターンが考えられる。前方車両との車間 距離 $G$ が安全車間距離 $G_{s}$ より小さく, かつ, $G$ が右 前方車閒距離 $G_{r}$ よりも小さい場合，右車線変更口一 カルルールを適用する。

自車両が右車線に存在する場合も同様である，Gが $G_{s}$ より小さく, かつ, $G$ が左前方車間距離 $G_{l}$ よりも 小さい場合, 左車線変更口一カルルールを適用する。

3.2.3 車線変更ローカルルール 車線変更には 右車線変更と左車線変更の2 種類があるが，左右が入 れ替わるだけなので図 6 で右車線変更ローカルルール について説明する。

車两が左車線を走行していて在に車線変更する場合， $G_{r b}$ が 6 セル $(18 \mathrm{~m})$ 以上であり，かつ， $G_{r}$ が 1 セル以 上であれば，右前セルを移動先セルとし，そうでなけ れば自車両の前方セルを移動先セルとする。

3.2 .4 速度ローカルルール 速度ローカルルール では，前方車両が十分離れている場合は最大值で加速 し，そうでない場合，2節で述心゙たモデルに従い，速 度を変更する。そのフローチャートを図 7 に示す。

本研究では，前力車再が 200 セル $(600 \mathrm{~m})$ 以上は なれているときに十分離れたと判断し，最大加速度 $2.4\left(\mathrm{~m} / \mathrm{sec}^{2}\right)$ で加速する。最大加速度の值は実測データ 


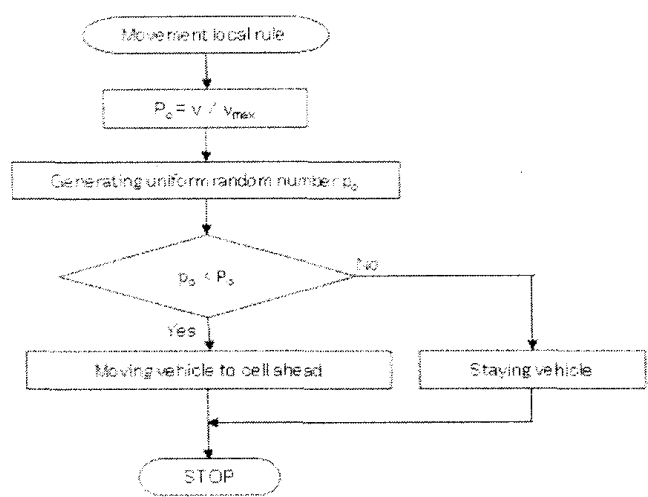

Fig. 8 Movement Local Rule

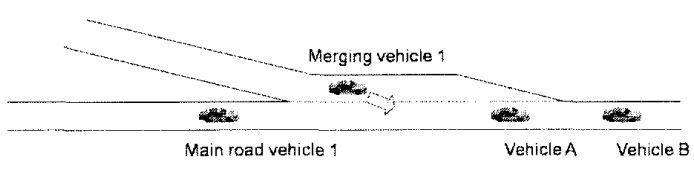

Fig. 9 Merging Point

を考慮して定められた值である(6). 前方 200 セル以内 に車両が存在する場合，2節で述べたモデルに従って 速度を変更する。追従モデルの場合は式 (1)によって， 拡張 Bexelius モデルの場合は式 (3)によって速度を変 更する。

3.2.5 移動ローカルルール 本研究のモデルで は，車両の移動をモデル化する車両遷移モデルとして

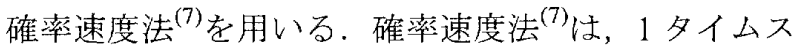
テップで最大 1 セルしか進まない車両遷移モデルであ る.アルゴリズムを図 8 に示す。

まず，車両速度 $V$ と領域内で全ての車両に対して設 定された最大速度 $V_{\max }$ から䦨值 $P_{0}$ を求める.

$$
P_{0}=\frac{V}{V_{\max }}
$$

次に, 0 から 1 の範囲で一様乱数 $p_{0}$ を発生し, $p_{0}<P_{0}$ のとき車両は 1 セル進み，そうでなければそのセルに とどまる.

\section{4. 解 析 例}

\section{1 問題設定本研究では，追従モデルと拡張} Bexelius モデルに従う車両を定義して道路合流部の交 通シミュレーションを行い，両者の結果を比較する. 車両合流の様子を図 9 に示す，本線と合流車線の車雨 最高速度を，それぞれ $80(\mathrm{~km} / \mathrm{h})$ と $40(\mathrm{~km} / \mathrm{h})$ とする。

この図では，本線車両 1 の前に合流車両 1 が合流し ている.この時, すでに本線を走行している車両 $\mathrm{A} と$ $\mathrm{B}$ が合流車両か否かが重要となる。つまり，これらの いずれかが合流車両の場合，1台だけ合流する場合よ
りも交通流の乱れが大きくなるからである。そこで， 以下の 4 つのパターンを考光る.

ケース 1 車両が 1 台だけ合流する場合を考える。つ まり，車両 AとBがともに本線を走行してきた 車両の場合である。

ケース 22 台続けて合流する場合を考える.つまり， 車両 $\mathrm{A}$ が合流した車両，車両 $\mathrm{B}$ が本線を走行し てきた車両の場合である。

ケース 33 台続けて合流する場合を考える.つまり，

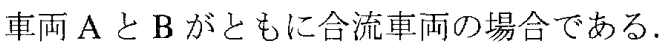

ケース 4 車両 $\mathrm{A}$ が本線を走行してきた車両, 車両 B が合流した車両である場合である。合流車両， 本線車雨，合流車両，本線車両の順番となり，い わゆるジッパー合流となる。

ケース 1 から 3 では, ケース 3 がもっとも交通流の乱 れが大きくなると予想される.ケース 4 のジッパー合 流は，同数の車雨が合流する外の場合に比べて，合流 による交通の乱れを抑えられるとされている。

\section{2 合流パターンの影響}

4.2.1 ケース 1 ケース 1 の合流の様子を図 10(a) に，合流後の速度遷移を図 10(b) と図 10(c) に示寸.

図 10(b) からわかるように，追従モデルでは合流車 両 1 によって本線車両が大きく速度を低下させている のに対して，図 10(c) からわかるように，拡張 Bexelius モデルでは速度低下を抑制できている，もっとも影響 の大きな本線車両 1 に着目すると, 速度低下は追従モ デルで $20 \%$ 程度，拡張 Bexelius モデルで $10 \%$ 程度 となり, 拡張 Bexelius モデルでは速度低下を半分程度 に抑えている。

4.2.2 ケース 2 ケース 2 の合流の様子を図 11(a) に，合流後の速度遷移を図 11(b) と図 11(c) に示寸。こ の場合，合流する 2 台は，同一タイムステップで合流 するとする。

追従モデルの場合，図 11(b) からわかるように合流 車両 2 は合流車両 1 の影響を受けて, 合流後の速度上 昇が遅れており，その影響を受けた本線車両 1 は，1 台だけ合流したケース 1 よりもさらに減速を強いられ ている. 本線車両 1 の減速の程度は, ケース 1 の場合 で $20 \%$ 程度だったのに対して，タース 2 では $37 \%$ 程 度に増大している.

それに対して，搪張 Bexelius モデルでは，図 11(c) からわかるように速度の回復が早く, 本線車両 1 の速 度減少の程度も小さくなっている. 本線車両 1 の速度 低下の程度は，追従モデルの場合 $37 \%$ 程度なのに対 して，拡張 Bexelius モデルの場合 $20 \%$ 程度に抑えら れている。 


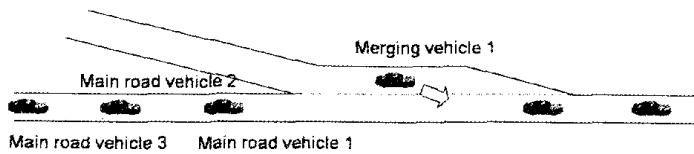

(a) Ullustration of Merging Vehicles

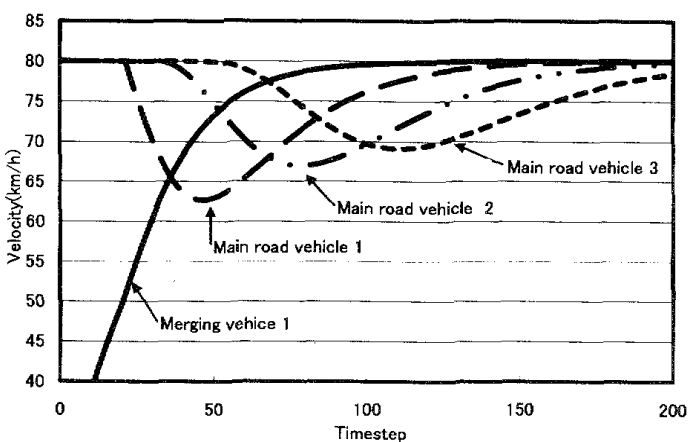

(b) Car-Following Model

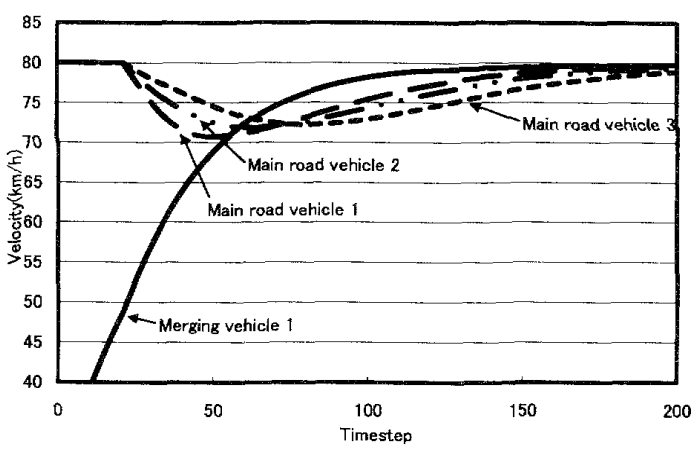

(c) Extended Bexelius Model

Fig. 10 Case- 1

4.2.3 ケース 3 ケース 3 では，3台の車両が続 けて合流する場合を考える。合流の様子を図 12(a)に， 合流後の速度遷移を図 12(b) と図 12(c) に示寸。この 場合，合流文る 3 台は，同一タイムステップで合流寸 るとする。

ケース 1 ，ケース 2 上同様に，ケース 3 においても 抗張 Bexelius モデルに従うほうが，より早く速度を回 復できている。もっとも影響の大きな本線車両 1 に着 目すると，速度低下は追従モデルで $40 \%$ 程度，拡張 Bexelius モデルで $30 \%$ 程度となり，拡張 Bexelius モ デルでは速度低下を追従モデルの3/4 程度に抑えられ ていることがわかる。

4.2.4 ケース 4 ケース 4 の合流の様子を図 13(a) に，合流後の速度遷移図 13(b) と図 13(c) に示亦。こ のケースは、ジッパー合流々呼ばれるものと概ね同じ

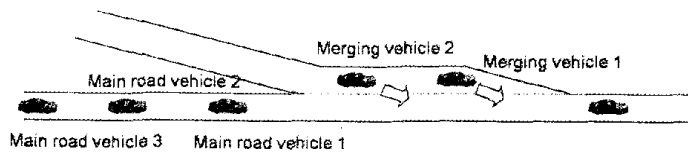

(a) Illustration of Merging Vehicles

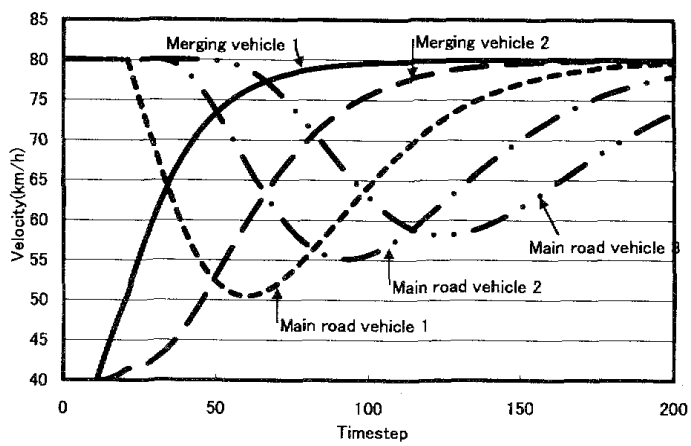

(b) Car-Following Model

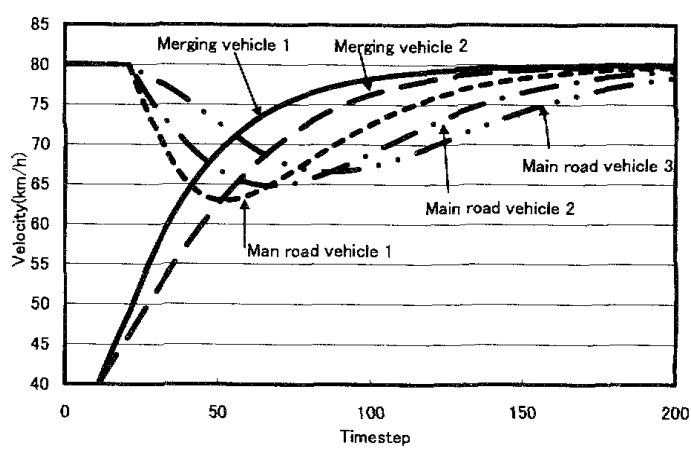

(c) Extended Bexelius Model

Fig. 11 Case-2

で女る、ジッパー合流とは，合流点付近で異なる車線 の車両が交互に並んで合流することで，スム一ズに合 流できるとされている。

図 13(b)からわかるように，追従モデルでは交通流 が大きく乱れている．特に，合流車両 2 に注目すると， 合流直後は加速するが，合流車両 1 の影響で減速中の 本線車軕 1 に追いくと減速に転じ, その後再び緩や かに加速寸る.このような合流車両 2 の加速の避れが 後に続く本線車両 $2,3,4$ の加速の遅れを生じている。

これに対して，应張 Bexelius モデルでは，図 13(c) からわかるように，合流車両2がなめらかに加速して いるので，それに続く本線車両 $2 ， 3 ， 4$ も早く速度回 復できている．合流車両 2 がなめらかに加速している のは拡張 Bexelius モデルの影響と考えられる。つま り，㹡張 Bexelius モデルでは前方 3 台の車雨に応答す 


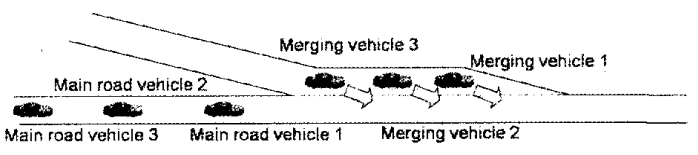

(a) Illustration of Merging Vehicles

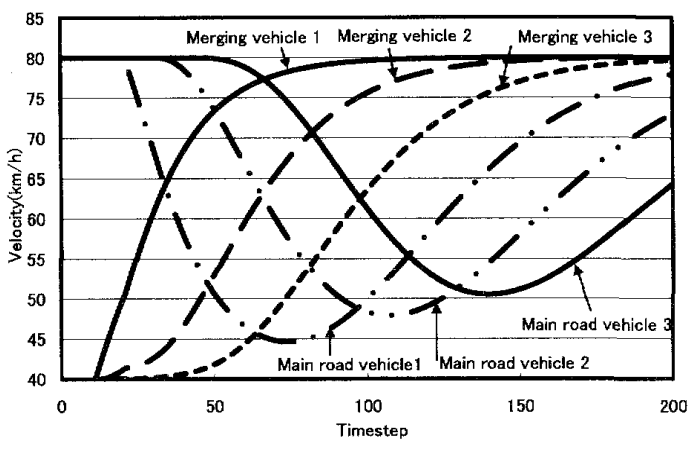

(b) Car-Following Model

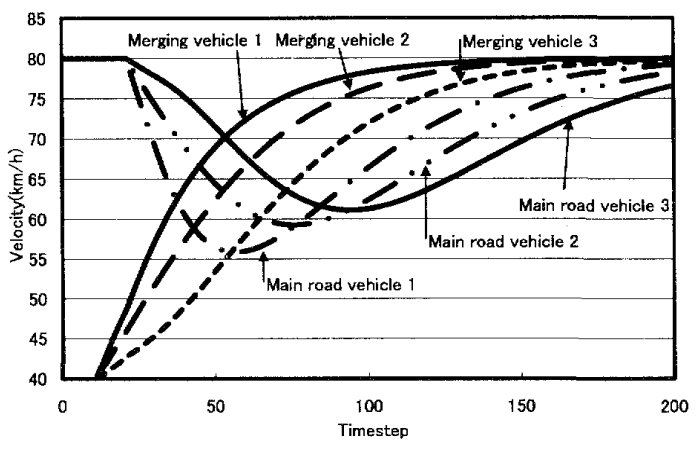

(c) Extended Bexelius Model

Fig. 12 Case-3

るので，直前の車両が減速していても，それより前の 車両を考慮することでなめらかに速度変化できるから である。

4.3 ケース 3 の車両遷移図前節において，追 従モデルと拡張 Bexelius モデルに従う車両をモデル化 し，合流車両が後方車両に与える影響を検討した，そ の中で，車両 3 台が同時に合流するケース 3 では，後 方車両の速度が大きく低下することを確認した。をこ で，本節ではタース 3 における合流直後の遷移図を用 いて，もう少し詳しく比較することにする．

追従モデルと拡張 Bexelius モデルに拉ける車両遷移 図を図 14 に示す。ここで，縌軸はタイムステップを 横軸は車両位置を示寸。車両は右方向に進行するので, 図中にお汁る白い線が車両の軌跡を意味する。

図 14(a), 図 14(b) 共に, シミュレーション開始時

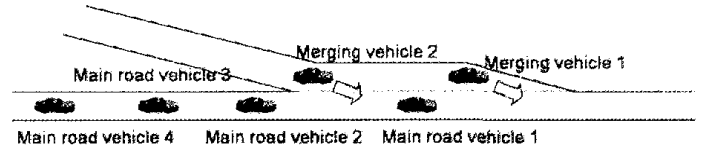

(a) Illustration of Merging Vehicles

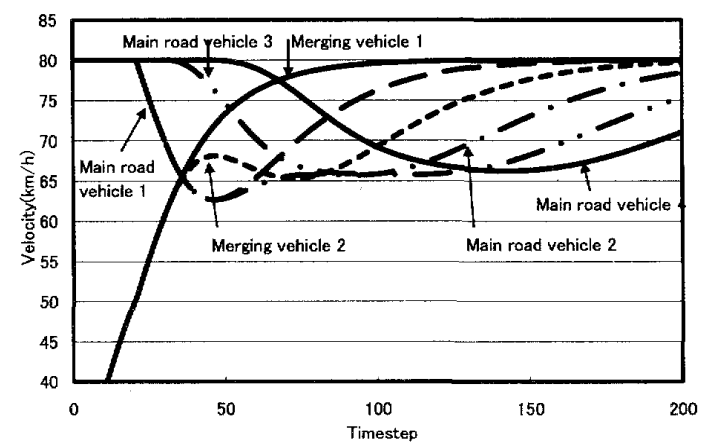

(b) Car-Following Model

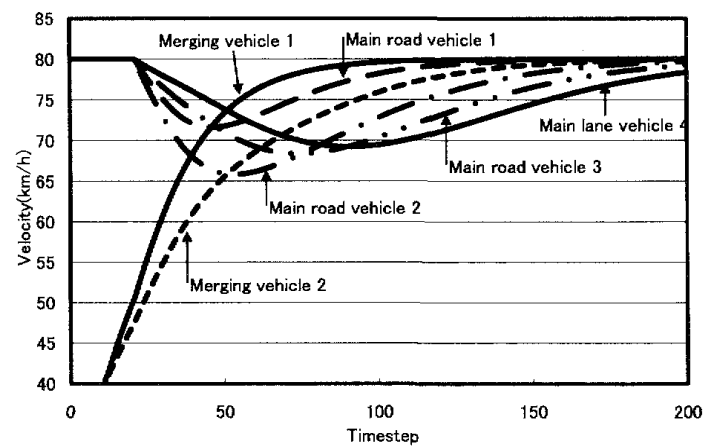

(c) Extended Bexelius Model

Fig. 13 Case-4

は，ほぼ等閒隔に車両が並んでいる。一定時間経過後， (1)の地点に車両が 3 台合流する，図 14(a) からわか るように, 追従モデルでは合流後合流地点よりも後方 の車両の軌跡が縦方向に伸びて橴滞を生じている，図 14(b)からわかるように，搪張 Bexelius モデルではそ のような様子は見られない。これらのことからも，桩 張 Bexelius モデルの利用が合流車両による渋滞発生を 改善できることがわかる.

\section{5. 結 論}

本研究では，道路合流部における啮滞緩和に対する 多追従モデルの一つである搪張 Bexelius モデルの有効 性を検討した。

まず，通常の追従モデルと拡張 Bexelius モデルを示 した。安定性解析から追従モデルと昖張 Bexelius モ 


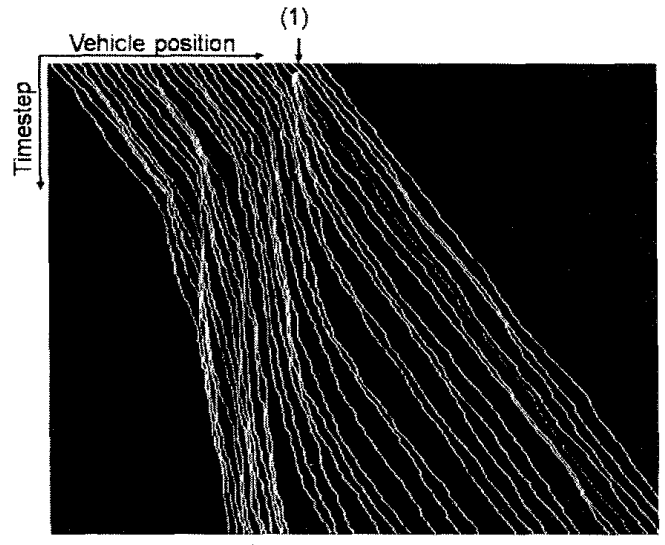

(a) Car-Following Model

(1)

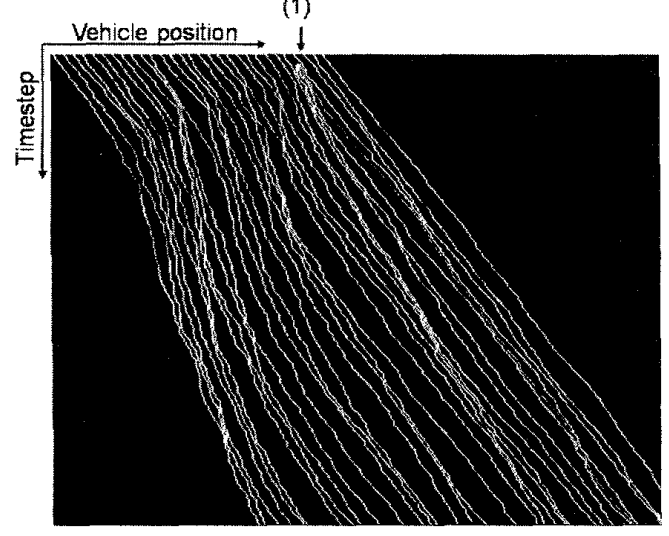

(b) Extended Bexelius Model

Fig. 14 Transition Diagram on Case 3

デルのパラメータを設計し， セルオートマトンシミュ レーションにおいて，2つのモデル党比較した。

シミュレー・ションでは，車王合流老 4 種類に分けて 解析した。 4 種類とは，車両 1 台の外合流寸るケース 1，車両 2 台が同時に合流するケース 2 ，車両 3 台が 同時に合流するケース $3 ， 2$ 台の車雨が合流車線から 本線走行車雨間にジッパー合流するケース 4 である.

ケース 1，2，3 では，追従モデルに従う車両の場 合，本線車両は大きく速度を落としていた。これに対 して，拡張 Bexelius モデルでは，追従モデルに比べて 速度の低下を抑制することができた。合流車雨の本線 車両人の影響がもつとも大きいケース 3 を取り上げる と，追従モデルでは車両合流によって本線車両速度は 最大 $40 \%$ 程度低下寸るのに対して，应張 Bexelius モ デルでは最大 $30 \%$ 程度に抑えられている。 その結果， いったん減少した本線車両の速度が元に戻るのに要す る時間は拡張 Bexelius モデルに䢨うことでかなり短縮 できた。
ジッパー合流で女る多一ス 4 では，本線車両の速度低 下が追徒モデルの場合で最大 $20 \%$ 程度, 拡張 Bexelius モデルの場合で最大 $18 \%$ 程度と比較的差が少なく, そ の点ではジッパー合流の有效性を示したといえる。し かし，应張 Bexelius モデルのほうが本線車雨の速度が 元に戻るのに要する時間が短く，それは後方車両に抒 いて特に顕著であった。つまり，合流車雨の直後を走 行古る本線車両よりも，より後方を走行する本線車両 についてみたとき，ジッパー合流においても追従モデ ルより桩張 Bexelius モデルに従う車両のほうが速度 低下が少なく，より速やかにもとの速度に復㷌できて wた.

以上のことより，複数の前方車両に応じて速度変化 する拡張 Bexelius モデルに従うことで, 前方 1 車両だ けに忘じて速度変化する追従モデルよりも交通渋滞を 緩和できる可能性があることが確譛できた。

現在, ITSの研究において全走行車両の情報省集め て中央で交通管制するシステムが開発されている，道 路状況によっては中央で集中管理することが困難な場 合も予想される。 そのような場合，地点每に自律分散 的に制御するほうが效果的とも考えられるので，本研 究で示した力法は，このような場合に合流点付近の交 通を自律分散的に制卸するために役立つと期待される。

\section{文献}

(1) Nishi R., Miki H., Tomoeda A. and Nishinari K., Simulations and Cluster Analysis of the Alternative Configuration of Vehicles on Weaving Section, Proceedings of the 14th Symposium on Simulation of Traffic Flow, Vol.14, (2008), pp.89-92, (in Japanese).

(2) Nakayama A., Car Following Models of 1-Dimensional Traffic Flow, Bulletin of the Japan Society for Industrial and Applied Mathematics, Vol.12, No.2 (2002), pp.109118 , (in Japanese).

(3) Sugiyama Y., Physics of Traffic Flow, Journal of Japan Society of Fluid Mechanics, Vol.22, No.2 (2003), pp.95108, (in Japanese).

(4) Bexelius S., An extended model for car-following. Transportaion Research, Vol.2 (1968), pp.13-21.

(5) Chandler R., Herman R. and Montroll W., Traffic dynamics; studies in car-following. Operation Research, Vol.6 (1958), pp.165-184.

(6) Tamaki T., Yasue S. and Kita E., City Traffic Simulation Using Cellular Automata with Stochastic Velocity Model. Proceedings of The 2004 International Conference on Parallel and Distributed Processing Techniques and Applications, (2004), (CD-ROM).

(7) Tamaki T., Yasue S. and Kita E., Traffic Simulation Using Stochastic Velocity Model and CA (ITS), Transactions of Information Processing Society of Japan, Vol.45, No.3 (2004), pp.858-869, (in Japanese). 